\title{
Wnt inhibitor XAV939 suppresses the viability of small cell lung cancer NCI-H446 cells and induces apoptosis
}

\author{
WENXUAN GUO, FANGZHEN SHEN, WENJING XIAO, JING CHEN and FEI PAN \\ Department of Oncology, Affiliated Hospital of Qingdao University, Qingdao, Shandong 266003, P.R. China
}

Received December 12, 2015; Accepted May 16, 2017

DOI: $10.3892 / 01.2017 .7100$

\begin{abstract}
Small cell lung cancer (SCLC) is the most aggressive type of lung cancer due to a fast tumor doubling time and early hematogenous spread. Advances in the treatment of non-small cell lung cancer using targeted therapies having been made, but no targeted drugs for SCLC have been approved. The Wnt signaling pathway is associated with tumor progression and metastasis; therefore, the inhibition of Wnt/ $/$-catenin signaling is a strategy for anticancer drugs. Tankyrase 1 (TNKS1) is overexpressed in a number of types of cancer and XAV939 is a small molecule inhibitor of TNKS1 which may inhibit tumor growth. The present study aimed to investigate the potential molecular mechanisms underlying XAV939-induced suppression of the viability of SCLC cells. MTT assays were used to determine the viability-inhibition rate of cells and to identify the drug concentration which optimally inhibited cell viability. Flow cytometry was used to determine whether XAV939 induced apoptosis of SCLC cells, and to analyze the effect of the drug on the cell cycle. The results of the present study identified that XAV939 inhibited the viability of NCI-H446 cells in a dose-dependent manner, but cisplatin inhibited NCI-H446 cell viability in a time- and dose-dependent manner. The combination of XAV939 and cisplatin exhibited a slightly more pronounced inhibition of cell viability at an increased dose of XAV939. In addition, XAV939 markedly induced cell apoptosis of the SCLC cell line $\mathrm{H} 446$ by increasing the proportion of cells in the $\mathrm{G}_{0} / \mathrm{G}_{1}$ phase, leading to inhibition of the cell cycle. The results of the present study indicated that XAV939 inhibited the viability of the NCI-H446 SCLC cell line by inducing cell apoptosis through the Wnt signaling pathway. Therefore, XAV939 may be useful for the treatment of SCLC.
\end{abstract}

Correspondence to: Dr Fangzhen Shen, Department of Oncology, Affiliated Hospital of Qingdao University, 16 Jiangsu Road, Qingdao, Shandong 266003, P.R. China

E-mail: shenfangzhen@163.com

Key words: small cell lung cancer, Wnt signaling pathway, XAV939, tankyrase, apoptosis, cell cycle

\section{Introduction}

Small cell lung cancer (SCLC) is an aggressive disease that accounts for $\sim 14 \%$ of all lung cancers, and there are $\sim 31,000$ patients who are diagnosed with SCLC annually in the USA (1). Due to the fast tumor doubling time and early hematogenous spread exhibited by SCLC, the 5-year survival rate remains $<5 \%$ and the median survival rate is between 7 and 12 months $(2,3)$. Unlike non-small cell lung cancer, in which major advances have been made using targeted therapies, there are no approved targeted drugs for SCLC (1). Therefore, the identification of effective targeted drugs is required.

One potential therapeutic target for lung cancer is the Wnt signaling pathway (4-7). Wnt signaling regulates cell proliferation, survival, and differentiation, and serves key functions in embryonic development and tumorigenesis (8-11). In the canonical Wnt signaling pathway, glycogen synthase kinase-3, in complex with axin and adenomatous polyposis coli, constitutively phosphorylates $\beta$-catenin, maintaining it at a decreased level (12). Poly-ADP-ribose polymerase (PARP) enzymes regulate the canonical Wnt activity: Tankyrase (TNKS) 1 and TNKS2. These two enzymes poly-ADP-ribosylate and destabilize axin, a key component of the $\beta$-catenin phosphorylation complex (12-14). TNKS1 has been identified to be upregulated in a variety of types of cancer, including plasma cell leukemia, high-grade non-Hodgkin's lymphoma, breast, colon and bladder cancer (15-20).

XAV939 is a small molecule TNKS inhibitor and is synthetized using a chemical genetics approach (21). Waaler et al (22) and Bilir et al (23) revealed that XAV939 suppressed the viability of colon cancer cells and triple-negative breast cancer cells by inhibiting Wnt signaling. However, the association between SCLC and the Wnt signaling pathway remains unknown. To the best of our knowledge, it has not been identified whether XAV939 exhibits an effect on SCLC cells, and it is hypothesized that the underlying molecular mechanism may contribute to establishing SCLC targeted therapy.

In the present study, the Wnt pathway inhibitor XAV939 was investigated in the effective treatment of SCLC cells and the inhibitory effect of XAV939 on the viability of SCLC cells was identified. In addition, the effect of XAV939 on the cell cycle and cell apoptosis was determined. The results of the present study revealed that XAV939 may inhibit the viability of SCLC via the repression of TNKS1, and TNKS1 may be a target for eliminating SCLC cells. 


\section{Materials and methods}

Chemicals and reagents. XAV939, MTT and dimethyl sulfoxide (DMSO) were purchased from Sigma-Aldrich; Merck KGaA (Darmstadt, Germany). The cisplatin injection was purchased from Hospira Australia Pty, Ltd. (Melbourne, Australia). The cell cycle detection kit and annexin V/fluorescein isothiocyanate (FITC) apoptosis detection kit was purchased from Nanjing KeyGEN Biotech. Co. Ltd. (Nanjing, China).

Cell culture. The NCI-H446 human SCLC cell line was purchased from the Institute of Biochemistry and Cell Biology (Shanghai Institutes for Biological Sciences, Chinese Academy of Science, Shanghai, China). Cells were cultured in RPMI-1640 medium, supplemented with $10 \%$ heat-inactivated fetal bovine serum, $2 \mathrm{mM}$ L-glutamine, $100 \mathrm{U} / \mathrm{ml}$ penicillin and $100 \mathrm{mg} / \mathrm{ml}$ streptomycin (all purchased from Gibco; Thermo Fisher Scientific, Inc., Waltham, MA, USA) under standard cell culture conditions $\left(37^{\circ} \mathrm{C}, 100 \%\right.$ relative humidity, atmosphere containing $5 \% \mathrm{CO}_{2}$ ).

MTT cell viability assays. To investigate the effectiveness of XAV939 targeting the Wnt signaling pathway in SCLC cells, the inhibitory effects XAV939 on the viability of H446 cells was determined. Cell viability was measured using an MTT colorimetric dye reduction assay, as previously described (24). The assays were divided into three groups and each group received various drug concentrations, as follows: XAV939 group $(2,4,8,16$ and $32 \mu \mathrm{M}$ XAV939), cisplatin group (1, 2, 4,8 and $10 \mathrm{mg} / \mathrm{l}$ cisplatin) and combination group $(2.0 \mathrm{mg} / \mathrm{l}$ cisplatin combined with $2,4,8,16$ or $32 \mu \mathrm{M}$ XAV939). Each experiment was performed in 96-well plates and repeated three times. The concentration range for treatment with each inhibitor was determined on the basis of previous studies $(12,25)$. A total of $1 \times 10^{5}$ NCI-H446 cells/well were seeded in 96-well plates and treated with the three groups drugs following incubation for $24 \mathrm{~h}$. Cells treated with the drugs were exposed for 24 or $48 \mathrm{~h}$ at $37^{\circ} \mathrm{C}$, following which the drug was removed. A total of $100 \mu \mathrm{l}$ MTT was added to each well and incubated for $4 \mathrm{~h}$. Subsequently, the medium was removed and $100 \mu \mathrm{l}$ DMSO was added to dissolve the solid formazan for $15 \mathrm{~min}$. The absorbance at a wavelength of $570 \mathrm{~nm}$ was then determined.

Apoptosis analysis. Apoptosis was determined using an annexin V/FITC apoptosis detection kit, according to the manufacturer's protocol. NCI-H446 cells $\left(1 \times 10^{6}\right.$ cells $\left./ \mathrm{ml}\right)$ were seeded into 6-well plates and subsequently treated with PBS (control) and XAV939 $(8,16$ and $32 \mu \mathrm{M})$ at $37^{\circ} \mathrm{C}$ for $24 \mathrm{~h}$. Cells were re-suspended in $500 \mu \mathrm{l} 1 \mathrm{X}$ binding buffer and incubated with Annexin V/FITC and propidium iodide (PI) for $20 \mathrm{~min}$ at room temperature in the dark. Cells were analyzed using fluorescence-activated cell sorting (FACSCalibur; BD Biosciences, San Jose, CA, USA) and FlowJo software (version 7.6; Tree Star Inc., Ashland, OR, USA).

Cell cycle analysis. Cell cycle was determined using a cell cycle detection kit (Nanjing KeyGEN Biotech. Co. Ltd.), according to the manufacturer's protocol. The assays were divided into

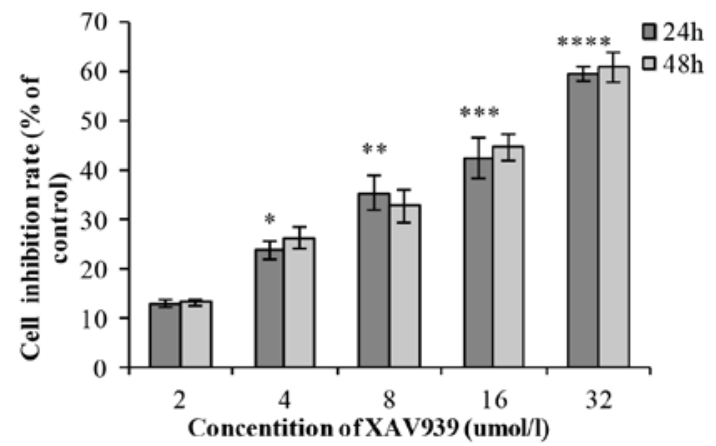

Figure 1. Cytotoxic effect of XAV939 on NCI-H446 cells. The viability of NCI-H446 cells incubated with 2, 4, 8, 16 and $32 \mu \mathrm{M}$ XAV939 for 24 and $48 \mathrm{~h}$ was assessed by MTT assay. Significant differences were observed in a concentration-dependent manner; however, there were no statistical significance differences as time increased. ${ }^{*} \mathrm{P}<0.01$ vs. $2 \mu \mathrm{M} ;{ }^{* *} \mathrm{P}<0.01$ vs. $4 \mu \mathrm{M}$; ${ }^{* * *} \mathrm{P}<0.01$ vs. $8 \mu \mathrm{M} ;{ }^{* * * * *} \mathrm{P}<0.01$ vs. $16 \mu \mathrm{M}$.

two groups: PBS control group and XAV939 group. NCI-H446 cells with a concentration of $1 \times 10^{6} / \mathrm{ml}$ were seeded into 6-well plates and treated with PBS (control), XAV939 (8, 16 and $32 \mu \mathrm{M}$ ) at $37^{\circ} \mathrm{C}$ for $24 \mathrm{~h}$. Cells were harvested and fixed with $70 \%$ ethanol at $4^{\circ} \mathrm{C}$ for $12 \mathrm{~h}$ and subsequently incubated at $37^{\circ} \mathrm{C}$ for $30 \mathrm{~min}$ with $100 \mu \mathrm{l}$ RNase A. A total of $400 \mu \mathrm{l}$ PI was added to the cells at $4^{\circ} \mathrm{C}$ in the dark for $30 \mathrm{~min}$. Cell cycle distribution was analyzed for 10,000 selected cells using the Aria II flow cytometer (BD Biosciences) at $488 \mathrm{~nm}$ wavelength. The resulting DNA distributions were analyzed using FlowJo software (version 7.6; Tree Star Inc.) to determine the proportion of cells in $G_{0} / G_{1}, S$ and $G_{2} / M$ phases of the cell cycle.

Statistical analysis. Statistical analysis was performed using SPSS software (version 17.0; SPSS, Inc., Chicago, IL, USA). Multiple group comparisons were made using one-way analysis of variance and the post-hoc tests were performed using LSD test and Dunnett t-test. $\mathrm{P}<0.05$ was considered to indicate a statistically significant difference.

\section{Results}

XAV939 effectively inhibits the viability of NCI-H446 cells. In the XAV939 group, with the increase of drug concentration $(2,4,8,16$ and $32 \mu \mathrm{M})$, the cell inhibition rate increased gradually and the difference was statistically significant $(\mathrm{P}<0.01$; Table I). As incubation time (24 or $48 \mathrm{~h}$ ) increased, the cell inhibition rate of each drug concentration increased gradually; however, there was no statistically significant difference between the 24 and $48 \mathrm{~h}$ ( $\mathrm{P}>0.05$; Table I). The half-maximal inhibitory concentration, $\mathrm{IC}_{50}$, was $20.02 \mu \mathrm{mol} / 1$. XAV939 induced an inhibitory effect on the viability of NCI-H446 cells in a dose-dependent manner (Fig. 1). Each experiment was performed three times.

Cisplatin inhibits the viability of NCI-H446 cells. Following treatment of cells with $1,2,4,8$ or $10 \mathrm{mg} / 1$ cisplatin for 24 or $48 \mathrm{~h}$, cell viability decreased in a time- and dose-dependent manner (Fig. 2). The difference was identified to be statistically significant (Table II). The $\mathrm{IC}_{50}$ was $2.056 \mathrm{mg} / \mathrm{l}$. 
Table I. NCI-H446 cell viability following treatment with XAV939.

\begin{tabular}{|c|c|c|c|c|}
\hline \multirow[b]{2}{*}{ Treatment } & \multicolumn{2}{|c|}{ Cell viability (\%) } & \multicolumn{2}{|c|}{$\begin{array}{l}\text { Comparison between } \\
\text { treatment durations }\end{array}$} \\
\hline & $24 \mathrm{~h}$ & $48 \mathrm{~h}$ & $\mathrm{~F}$ & P-value \\
\hline \multicolumn{5}{|c|}{ XAV939, $\mu \mathrm{M}$} \\
\hline 2 & $12.99 \pm 0.78$ & $13.18 \pm 0.63$ & 0.500 & 0.855 \\
\hline 4 & $23.78 \pm 1.83$ & $26.30 \pm 2.18$ & 0.135 & 0.426 \\
\hline 8 & $35.45 \pm 3.50$ & $32.72 \pm 3.30$ & 0.043 & 0.602 \\
\hline 16 & $42.50 \pm 4.10$ & $44.64 \pm 2.69$ & 0.231 & 0.686 \\
\hline 32 & $59.57 \pm 1.45$ & $60.89 \pm 3.03$ & 2.985 & 0.715 \\
\hline \multicolumn{5}{|c|}{ Comparison between treatment concentrations } \\
\hline $\mathrm{F}$ & 45.027 & 50.605 & & \\
\hline P-value & $<0.001^{\mathrm{a}}$ & $<0.001^{\mathrm{a}}$ & & \\
\hline
\end{tabular}

Data are presented as the mean \pm standard deviation. ${ }^{a} \mathrm{P}<0.01,{ }^{\mathrm{b}} \mathrm{P}<0.05$ vs. control.

Table II. NCI-H446 cell viability following treatment with cisplatin.

\begin{tabular}{|c|c|c|c|c|}
\hline \multirow[b]{2}{*}{ Treatment } & \multicolumn{2}{|c|}{ Cell viability (\%) } & \multicolumn{2}{|c|}{$\begin{array}{l}\text { Comparison between } \\
\text { treatment durations }\end{array}$} \\
\hline & $24 \mathrm{~h}$ & $48 \mathrm{~h}$ & $\mathrm{~F}$ & P-value \\
\hline \multicolumn{5}{|c|}{ Cisplatin, mg/l } \\
\hline 1 & $30.26 \pm 2.58$ & $36.61 \pm 0.99$ & 4.277 & 0.084 \\
\hline 2 & $58.03 \pm 0.58$ & $64.32 \pm 1.10$ & 1.818 & $0.007^{\mathrm{b}}$ \\
\hline 4 & $64.18 \pm 1.02$ & $71.40 \pm 0.62$ & 1.837 & $0.004^{\mathrm{b}}$ \\
\hline 8 & $73.05 \pm 0.71$ & $78.47 \pm 0.76$ & 0.028 & $0.007^{\mathrm{b}}$ \\
\hline 10 & $71.98 \pm 1.19$ & $82.23 \pm 1.09$ & 0.007 & $0.003^{\mathrm{b}}$ \\
\hline \multicolumn{5}{|c|}{ Comparison between treatment concentrations } \\
\hline $\mathrm{F}$ & 151.939 & 107.277 & & \\
\hline P-value & $<0.001^{\mathrm{a}}$ & $<0.001^{\mathrm{a}}$ & & \\
\hline
\end{tabular}

Data are presented as the mean \pm standard deviation. ${ }^{\mathrm{a}} \mathrm{P}<0.01,{ }^{\mathrm{b}} \mathrm{P}<0.05$ vs. control.

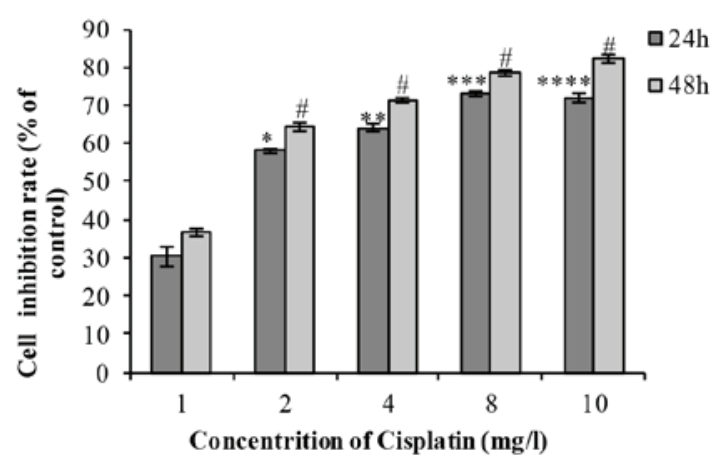

Figure 2. Cytotoxic effect of cisplatin on NCI-H446 cells. Viability of NCI-H446 cells incubated with $1,2,4,8$ and $10 \mathrm{mg} / 1$ cisplatin for 24 and $48 \mathrm{~h}$. Significant differences were observed in a concentration- and time-dependent manner. ${ }^{*} \mathrm{P}<0.01$ vs. $1 \mathrm{mg} / 1 ;{ }^{* *} \mathrm{P}<0.01$ vs. $2 \mathrm{mg} / 1 ;{ }^{* * * *} \mathrm{P}<0.01$ vs. $4 \mathrm{mg} / \mathrm{l} ;{ }^{* * * * *} \mathrm{P}<0.01$ vs. $8 \mathrm{mg} / 1 ;{ }^{\#} \mathrm{P}<0.01$ vs. $24 \mathrm{~h}$.

Combination treatment inhibits the viability of NCI-H446 cells. In the combination group, the cell inhibition rate increased with the extension of time $(24$ or $48 \mathrm{~h})$ and with XAV939 concentration $(2,4,8,16$ or $32 \mu \mathrm{M})$. The results of the present study indicated that a combination of the two drugs effectively inhibited NCI-H446 cell viability in a dose- and time-dependent manner (Table III; Fig. 3). When distinct concentrations of XAV939 were combined with cisplatin $(2.0 \mathrm{mg} / \mathrm{l})$, the inhibition of NCI-H446 cell viability was slightly decreased at low doses compared with XAV939 treatment alone, and was slightly increased at high doses compared with XAV939 treatment alone (Fig. 4). However, there was no statistically significant difference between combination group and the XAV939 group at any concentration of XAV939.

XAV939 induces NCI-H446 cell apoptosis. To determine whether the inhibitory effect of XAV939 on cell viability was associated with the induction of cell apoptosis, NCI-H446 cells were treated with a variety of concentrations $(0,8,16$ and $32 \mu \mathrm{M}$ ) of XAV939 for $24 \mathrm{~h}$. The proportion of apoptotic 
Table III. Cell viability of NCI-H446 cells following combined treatment of XAV939 of the indicated concentrations and $2.0 \mathrm{mg} / \mathrm{l}$ cisplatin.

\begin{tabular}{|c|c|c|c|c|}
\hline \multirow[b]{2}{*}{ Treatment } & \multicolumn{2}{|c|}{ Cell viability (\%) } & \multicolumn{2}{|c|}{$\begin{array}{l}\text { Comparison between } \\
\text { treatment durations }\end{array}$} \\
\hline & $24 \mathrm{~h}$ & $48 \mathrm{~h}$ & F & P-value \\
\hline \multicolumn{5}{|c|}{ XAV939, $\mu \mathrm{M}$} \\
\hline 2 & $9.11 \pm 0.48$ & $12.62 \pm 0.45$ & 0.058 & $0.006^{\mathrm{b}}$ \\
\hline 4 & $18.66 \pm 0.73$ & $23.55 \pm 0.56$ & 0.535 & $0.003^{\mathrm{b}}$ \\
\hline 8 & $33.07 \pm 0.56$ & $38.37 \pm 0.60$ & 0.001 & $0.003^{\mathrm{b}}$ \\
\hline 16 & $46.26 \pm 1.17$ & $53.81 \pm 1.06$ & 0.001 & $0.008^{b}$ \\
\hline 32 & $65.22 \pm 1.61$ & $70.34 \pm 0.38$ & 2.267 & $0.036^{\mathrm{b}}$ \\
\hline \multicolumn{5}{|c|}{ Comparison between treatment concentrations } \\
\hline $\mathrm{F}$ & 490.954 & 1228.98 & & \\
\hline P-value & $<0.001^{\mathrm{a}}$ & $<0.001^{\mathrm{a}}$ & & \\
\hline
\end{tabular}

Data are presented as the mean \pm standard deviation. ${ }^{a} \mathrm{P}<0.01,{ }^{b} \mathrm{P}<0.05$ vs. control.

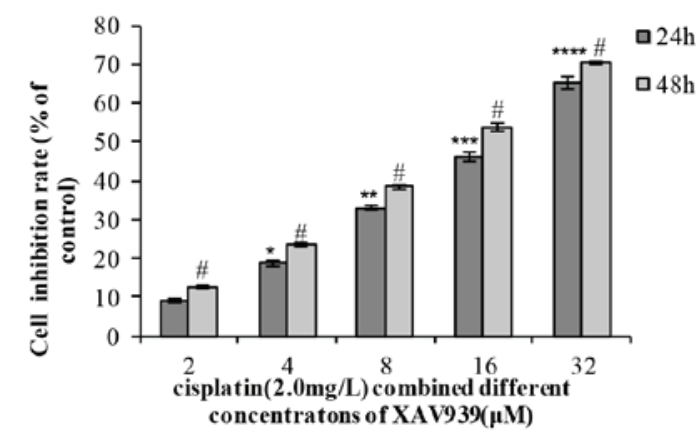

Figure 3. Cytotoxic effect of the combination group on NCI-H446 cells. Viability of NCI-H446 cells incubated with a variety of concentrations $(2,4,8,16$ or $32 \mu \mathrm{M})$ of XAV939 combined with cisplatin $(2.0 \mathrm{mg} / \mathrm{l})$ for 24 and $48 \mathrm{~h}$. Significant differences were observed in a concentration- and time-dependent manner. ${ }^{*} \mathrm{P}<0.01$ vs. $2 \mu \mathrm{M} ;{ }^{* *} \mathrm{P}<0.01$ vs. $4 \mu \mathrm{M} ;{ }^{* * * *} \mathrm{P}<0.01$ vs. $8 \mu \mathrm{M} ;{ }^{* * * * * *} \mathrm{P}<0.01$ vs. $16 \mu \mathrm{M} ;{ }^{*} \mathrm{P}<0.05$ vs. $24 \mathrm{~h}$.

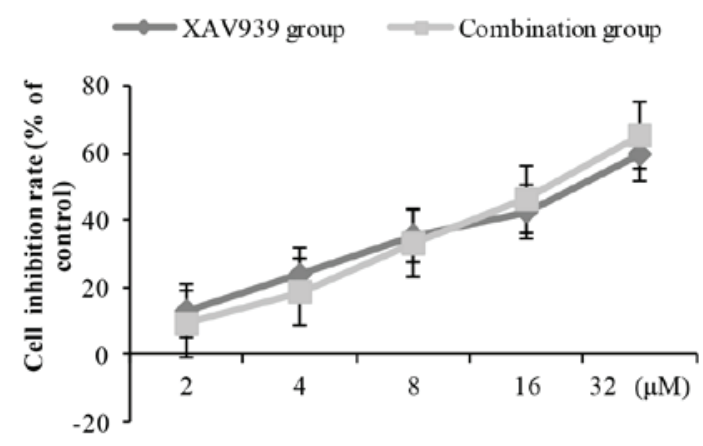

Figure 4. Interactions between XAV939 and cisplatin. When distinct concentrations of XAV939 were combined with cisplatin $(2.0 \mathrm{mg} / \mathrm{l})$, the inhibition of NCI-H446 cell viability was slightly weakened at low doses and slightly strengthened at high doses.

NCI-H446 cells increased with XAV939 dosage $(\mathrm{P}<0.05$; Fig. 5), suggesting that the XAV939 may induce increased apoptosis at increased concentrations.
Cell cycle analysis. When the drug group was compared with the control group, the $G_{0} / G_{1}$ phase cell proportion increased significantly, and the $S$ phase to $G_{2} / M$ ratio markedly decreased. The difference exhibited a statistical significance $(\mathrm{P}<0.05$; Fig. 6). Cell cycle analysis, using flow cytometry, revealed a dose-dependent increase in the accumulation of cells in $\mathrm{G}_{0} / \mathrm{G}_{1}$ phase $(\mathrm{P}<0.05$; Fig. 6), indicating that XAV939 induced cell apoptosis by cell cycle inhibition.

\section{Discussion}

The typical treatment for SCLC is systemic chemotherapy, which exhibits a curative effect; however, the recurrence rate is high, indicating a requirement to develop more effective and targeted therapy options for patients with SCLC. Aberrant activation of Wnt signaling, which serves a key function in the regulation of cell viability, development and differentiation, has been associated with a number of types of cancer including colorectal, prostate, liver, and breast cancer $(10,11,26,27)$. Thus, inhibition of Wnt signaling may be an effective approach to the treatment of distinct types of cancer.

A number of signaling pathway inhibitors have been used to suppress tumor growth. Dickkopf-related protein 1 (28) and secreted frizzled-related proteins (29) are typical Wnt antagonists. XAV939, a novel small molecule Wnt signaling pathway inhibitor, may restrain the abnormal activation of Wnt/ $\beta$-catenin and exhibit no effect on the normal function of cells. XAV939 may inhibit the activity of tankyrases and may, through poly-ADP-ribosylation, stabilize axin and inhibit Wnt signaling pathways. Compared with other Wnt pathway inhibitors, XAV939 exhibits a strong specificity for the Wnt signaling pathway, without influencing NF-kB or TGF-B signaling pathways.

Huang et al (13) and Chen et al (14) validated that XAV939 inhibited the viability of colon cancer cells by suppressing Wnt signaling, through binding to the catalytic PARP domain of TNKS. In addition, Bilir et al (23) identified that XAV939 inhibited the viability of triple-negative breast cancer cells by 

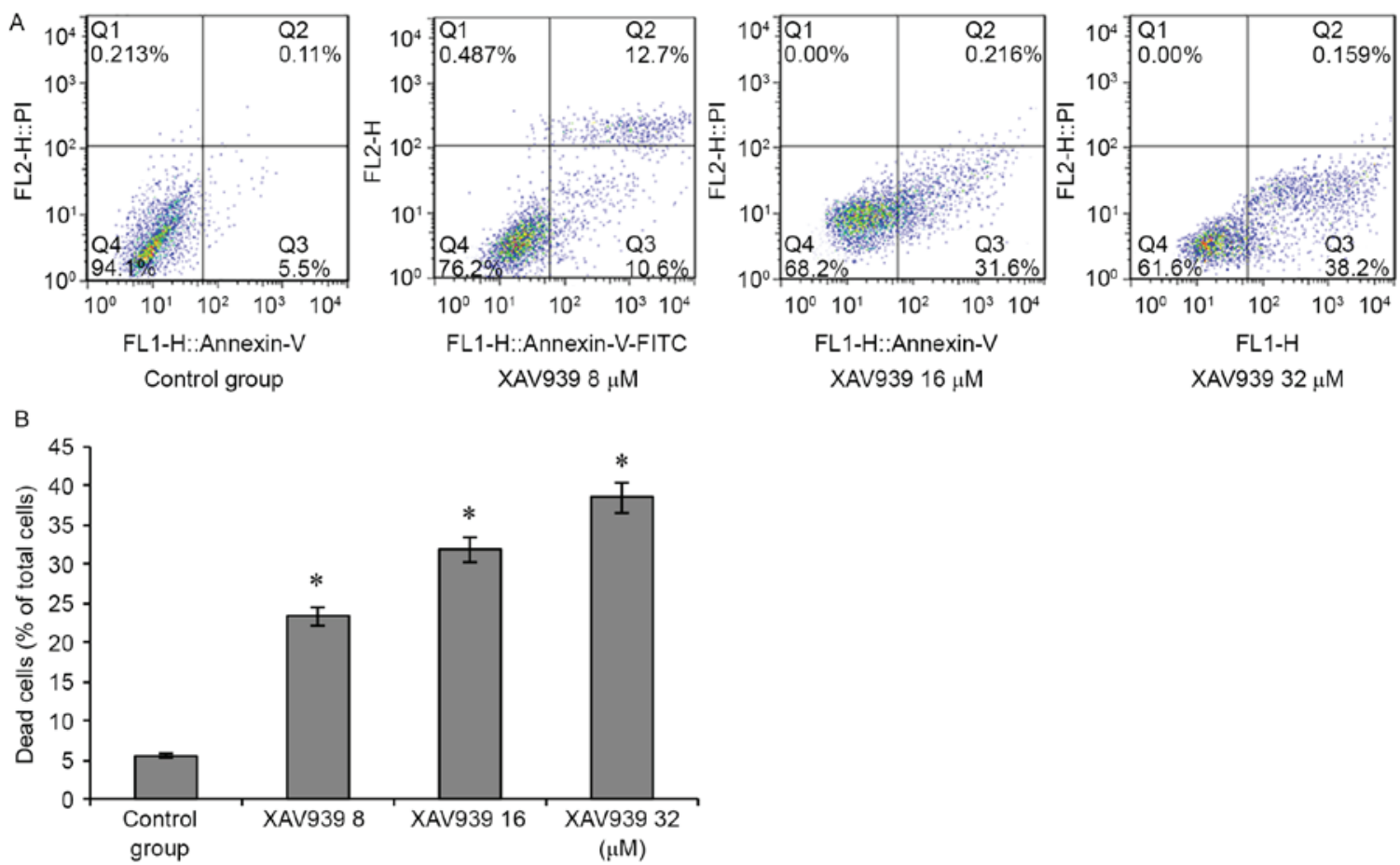

Figure 5. XAV939 induces cell apoptosis in NCI-H446 cells. (A) NCI-H446 cells were incubated with the indicated concentrations of XAV939 for 24 h and cell apoptosis was subsequently analyzed using annexin V and PI double-staining flow cytometry. (B) The proportion of apoptotic NCI-H446 cells increased with XAV939 dosage. ${ }^{\text {P }}$ <0.05 vs. control. PI, propidium iodide; FITC, fluorescein isothiocyanate; FL1-H, cells stained by annexin V; FL2-H, cells stained by PI.

A

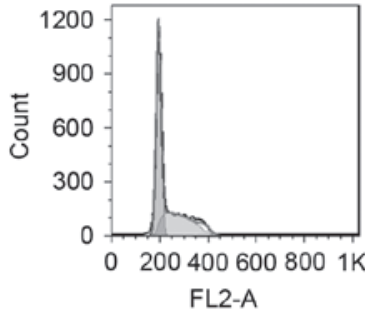

Control group

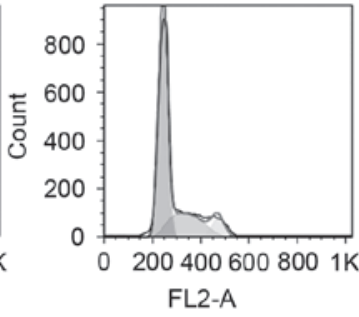

XAV939 $8 \mu \mathrm{M}$

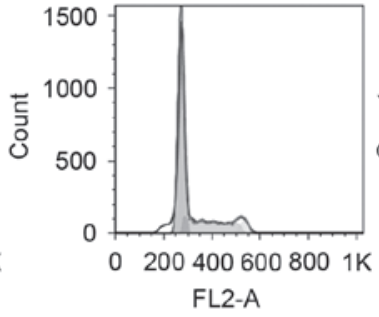

XAV939 $16 \mu \mathrm{M}$

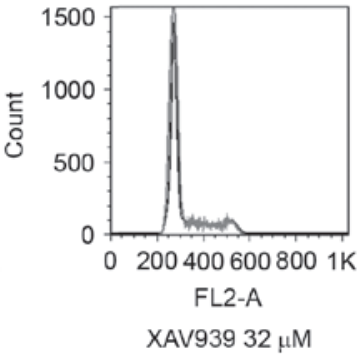

XAV939 $32 \mu \mathrm{M}$

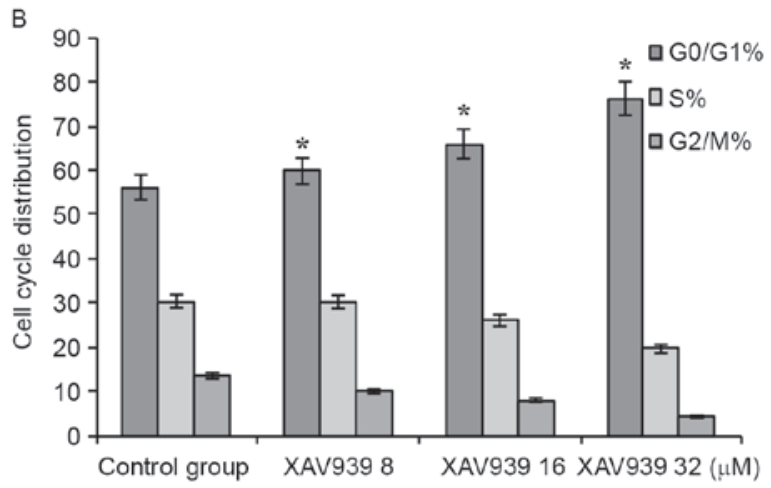

Figure 6. XAV939 induces cell cycle inhibition in NCI-H446 cells. (A) NCI-H446 cells were incubated with distinct concentrations of XAV939 for 24 h, stained with propidium iodide and analyzed for DNA content using flow cytometry. (B) XAV939 induced cell cycle arrest at $\mathrm{G}_{0} / \mathrm{G}_{1}$ phase in dose-dependent manner. "P<0.05 vs. control. FL2-A, area of fluorescence peak.

suppressing Wnt signaling. Shao et al (30) used XAV939 in combination with nedaplatin on HeLa cells, indicating that XAV939 inhibits the viability of cervical cancer cells. To determine whether XAV939 is able to inhibit the viability of SCLC cells, an MTT assay was used. Following treatment with
XAV939, a marked inhibition of cell viability in the SCLC cells was observed. When XAV939 was combined with cisplatin, the inhibition of viability of NCI-H446 cells was slightly weakened at a low dose and was slightly strengthened at a high dose compared with XAV939 treatment alone. However, there was no 
statistically significant difference between combination group and the XAV939 alone group at any concentration of XAV939.

The effect of XAV939 on the apoptosis of SCLC cells and the cell cycle was analyzed using flow cytometry. Flow cytometry analysis indicated that XAV939 inhibited the viability of NCI-H446 cells. The proportion of apoptotic NCI-H446 cells increased with XAV939 dosage. In addition, cell cycle analysis revealed a dose-dependent increased accumulation of cells in $\mathrm{G}_{0} / \mathrm{G}_{1}$ phase. The underlying molecular mechanism of apoptosis induction may be as follows: XAV939 decreases the level of $\beta$-catenin in the Wnt signaling pathway and prevents it from binding to $\mathrm{T}$ cell factor/lymphoid enhancer-binding factor, thus inhibiting the expression of downstream target gene c-myc and Cyclin D1. C-myc gene, an oncogene, primarily functions in the cell cycle and is the switch between $G_{0} / G_{1}$ and $S$ phase. When the Wnt signaling pathway is activated, c-myc gene is expressed, which causes the cells to transition from the quiescent period into the proliferative phase, and promotes cancer cell proliferation, invasion and metastasis $(31,32)$. Cyclin D1 is a specific cyclin that acts on the $G_{1}$ phase, which is highly conserved, and promotes dysregulated cell proliferation and malignancy by regulating cyclin-dependent kinase to promote $\mathrm{G}_{1} / \mathrm{S}$ phase conversion (33). XAV939 inhibited the expression of c-myc gene and Cyclin D1 by blocking the signal pathway. The cells were arrested in $\mathrm{G}_{0} / \mathrm{G}_{1}$ phase and induced apoptosis. Furthermore, Yang et al (34) identified that XAV939 induced $\mathrm{G}_{0} / \mathrm{G}_{1}$ phase inhibition in acute lymphoblastic leukemia cells, which is consistent with this study.

The results of the present study preliminary validate XAV939-induced inhibition of cell viability in SCLC, and also provides a reference basis and theoretical support for SCLC targeted therapy. Additional studies on the basis of targeting gene expression to intervene in and inhibit tumor growth, are required. Inhibition of SCLC-associated signaling pathways may provide an effective method of treatment (35).

\section{References}

1. Byers LA and Rudin CM: Small cell lung cancer: Where do we go from here? Cancer 121: 664-672, 2015.

2. Merrill RM, Henson DE and Barnes M: Conditional survival among patients with carcinoma of the lung. Chest 116: 697-703, 1999.

3. Gustafsson BI, Kidd M, Chan A, Malfertheiner MV and Modlin IM: Bronchopulmonary neuroendocrine tumors. Cancer 113: 5-21, 2008

4. Snow GE, Kasper AC, Busch AM, Schwarz E, Ewings KE, Bee T, Spinella MJ, Dmitrovsky E and Freemantle SJ: Wnt pathway reprogramming during human embryonal carcinoma differentiation and potential for therapeutic targeting. BMC Cancer 9: 383, 2009.

5. You L, He B, Xu Z, Uematsu K, Mazieres J, Mikami I, Reguart N, Moody TW, Kitajewski J, McCormick F and Jablons DM: Inhibition of Wnt-2-mediated signaling induces programmed cell death in non-small-cell lung cancer cells. Oncogene 23 6170-6174, 2004

6. Pacheco-Pinedo EC, Durham AC, Stewart KM, Goss AM, Lu MM, Demayo FJ and Morrisey EE: Wnt $/ \beta$-catenin signaling accelerates mouse lung tumorigenesis by imposing an embryonic distal progenitor phenotype on lung epithelium. J Clin Invest 121: 1935-1945, 2011.

7. Nguyen DX, Chiang AC, Zhang XH, Kim JY, Kris MG, Ladanyi M, Gerald WL and Massagué J: WNT/TCF signaling through LEF1 and HOXB9 mediates lung adenocarcinoma metastasis. Cell 138: 51-62, 2009.

8. Howe LR and Brown AM: Wnt signaling and breast cancer. Cancer Biol Ther 3: 36-41, 2004.
9. Khramtsov AI, Khramtsova GF, Tretiakova M, Huo D, Olopade OI and Goss KH: Wnt/beta-catenin pathway activation is enriched in basal-like breast cancers and predicts poor outcome. Am J Pathol 176: 2911-2920, 2010.

10. MacDonald BT, Tamai K and He X: Wnt/beta-catenin signaling: Components, mechanisms, and diseases. Dev Cell 17: 9-26, 2009.

11. Polakis P: Wnt signaling in cancer. Cold Spring Harb Perspect Biol 4: a008052, 2012

12. Busch AM, Johnson KC, Stan RV, Sanglikar A, Ahmed Y, Dmitrovsky E and Freemantle SJ: Evidence for tankyrases as antineoplastic targets in lung cancer. BMC Cancer 13: 211, 2013.

13. Huang SM, Mishina YM, Liu S, Cheung A, Stegmeier F, Michaud GA, Charlat O, Wiellette E, Zhang Y, Wiessner S, et al: Tankyrase inhibition stabilizes axin and antagonizes Wnt signalling. Nature 461: 614-620, 2009.

14. Chen B, Dodge ME, Tang W, Lu J, Ma Z, Fan CW, Wei S, Hao W, Kilgore J, Williams NS, et al: Small molecule-mediated disruption of Wnt-dependent signaling in tissue regeneration and cancer. Nat Chem Biol 5: 100-107, 2009.

15. MacNamara B, Wang W, Chen Z, Hou M, Mazur J, Gruber A and Porwit-MacDonald A: Telomerase activity in relation to pro- and anti-apoptotic protein expression in high grade non-Hodgkin's lymphomas. Haematologica 86: 386-393, 2001.

16. Klapper W, Krams M, Qian W, Janssen D and Parwaresch R: Telomerase activity in B-cell non-Hodgkin lymphomas is regulated by hTERT transcription and correlated with telomere-binding protein expression but uncoupled from proliferation. Br J Cancer 89: 713-719, 2003.

17. Gelmini S, Poggesi M, Distante V, Bianchi S, Simi L, Luconi M, Raggi CC, Cataliotti L, Pazzagli M and Orlando C: Tankyrase, a positive regulator of telomere elongation, is over expressed in human breast cancer. Cancer Lett 216: 81-87, 2004.

18. Gelmini S, Poggesi M, Pinzani P, Mannurita SC, Cianchi F, Valanzano $R$ and Orlando C: Distribution of Tankyrase-1 mRNA expression in colon cancer and its prospective correlation with progression stage. Oncol Rep 16: 1261-1266, 2006.

19. Gelmini S, Quattrone S, Malentacchi F, Villari D, Travaglini F, Giannarini G, Della Melina A, Pazzagli M, Nicita G, Selli C and Orlando C: Tankyrase-1 mRNA expression in bladder cancer and paired urine sediment: Preliminary experience. Clin Chem Lab Med 45: 862-866, 2007.

20. Shervington A, Patel R, Lu C, Cruickshanks N, Lea R, Roberts G, Dawson T and Shervington L: Telomerase subunits expression variation between biopsy samples and cell lines derived from malignant glioma. Brain Res 1134: 45-52, 2007.

21. Tian X, Hou W, Bai S, Fan J, Tong H and Xu H: XAV939 inhibits the stemness and migration of neuroblastoma cancer stem cells via repression of tankyrase 1. Int J Oncol 45: 121-128, 2014.

22. Waaler J, Machon O, Tumova L, Dinh H, Korinek V, Wilson SR, Paulsen JE, Pedersen NM, Eide TJ, Machonova O, et al: A novel tankyrase inhibitor decreases canonical Wnt signaling in colon carcinoma cells and reduces tumor growth in conditional APC mutant mice. Cancer Res 72: 2822-2832, 2012.

23. Bilir B, Kucuk O and Moreno CS: Wnt signaling blockage inhibits cell proliferation and migration, and induces apoptosis in triple-negative breast cancer cells. J Transl Med 11: 280, 2013.

24. Zare Jahromi M, Ranjbarian P and Shiravi S: Cytotoxicity evaluation of Iranian propolis and calcium hydroxide on dental pulp fibroblasts. J Dent Res Dent Clin Dent Prospects 8: 130-133, 2014.

25. Fong JT, Jacobs RJ, Moravec DN, Uppada SB, Botting GM, Nlend $M$ and Puri N: Alternative signaling pathways as potential therapeutic targets for overcoming EGFR and c-Met inhibitor resistance in non-small cell lung cancer. PLoS One 8: e78398, 2013.

26. Moon RT: Wnt/ $\beta$-catenin pathway. Science's STKE 2005: $\mathrm{cm} 1$, 2005.

27. Klaus $\mathrm{A}$ and Birchmeier W: Wnt signalling and its impact on development and cancer. Nat Rev Cancer 8: 387-398, 2008.

28. Salim H, Zong D, Hååg P, Novak M, Mörk B, Lewensohn R, Lundholm L and Viktorsson K: DKK1 is a potential novel mediator of cisplatin-refractoriness in non-small cell lung cancer cell lines. BMC Cancer 15: 628, 2015.

29. Shi Y, He B, You L and Jablons DM: Roles of secreted frizzled-related proteins in cancer. Acta Pharmacol Sin 28: 1499-1504, 2007. 
30. Shao W and Wang W: Experimental and basic research affect telomerase inhibitor XAV939 joint nedaplatin on HeLa cell proliferation and apoptosis. Maternal and Child Health Care of China 19: 1001-4411, 2014.

31. Partanen JI, Nieminen AI, Mäkelä TP and Klefstrom J: Suppression of oncogenic properties of c-Myc by LKB1-controlled epithelial organization. Proc Natl Acad Sci USA 104: 14694-14699, 2007

32. Li Y, Guessous F, Johnson EB, Eberhart CG, Li XN, Shu Q, Fan S, Lal B, Laterra J, Schiff D, et al: Functional and molecular interactions between the HGF/c-Met pathway and c-Myc in large-cell medulloblastoma. Lab Invest 88: 98-111, 2008.

33. Jirawatnotai S, Hu Y, Livingston DM and Sicinski P: Proteomic identification of a direct role for cyclin d1 in DNA damage repair. Cancer Res 72: 4289-4293, 2012.
34. Yang Y, Mallampati S, Sun B, Zhang J, Kim SB, Lee JS, Gong Y, Cai $Z$ and Sun $X$. Wnt pathway contributes to the protection by bone marrow stromal cells of acute lymphoblastic leukemia cells and is a potential therapeutic target. Cancer Lett 333: 9-17, 2013.

35. Dihlmann $S$ and von Knebel Doeberitz M: Wnt/ beta-catenin-pathway as a molecular target for future anti-cancer therapeutics. Int J Cancer 113: 515-524, 2005. 